\title{
The European Crisis and the Peace Treaties
}

\section{By Professor Emilit Mireaux}

Ecole Normale Superieure and Société d'Etudes et d'Informations Economiques

\section{“ $T$}

THE Economic Consequences of the Peace,"-disastrous consequences, of course. Few phrases have been more widely re-echoed than this one, which the talent of Mr. Keynes has made popular throughout the world. The peace has proved disappointing. Full of the remembrance of the past, men had conceived of her as the very picture of plenty and robustness; like the old allegorical figures, her arms heavily laden with flowers and fruit. They had been waiting for her so long, they had been so ardently wishing for her return, that they have felt astonished at the pettiness of her gifts. They had looked forward to her generosity; she has behaved like a niggard. She has not brought back prosperity. Balked of their expectations, men have begun inveighing against her. Post hoc, ergo propter hoc. The peace has been made responsible for the economic distress that has followed upon her heels. The crisis has come to be regarded as "the economic consequence of the peace."

The success of such a viewpoint is not surprising. What could better appeal to the delusions of all those who cannot reconcile themselves to the idea that our present straits are due to long-working deep-seated lasting causes, and who flatter themselves with the hope that, in order to cure all the ailments of Europe, nothing more is required than modifying a few texts by means of which unskilful wizards have cast an evil spell over the world.

Whoever takes it for granted, however, that a well-devised, or a betterdevised peace would be able to re- endow the European economic organism with its pristine vigor, indulges in a strange conceit and singularly overlooks facts as they are. Though one almost blushes to recall so obvious a truth, one must not get weary of emphasizing the true origin of the trials of the Old Continent. We are going through the economic consequences, not of the peace, but of the war.

Of those consequences, by far the most important is the general impoverishment of Europe. Even the lands which have least experienced the havoc of war, such as Germany or Great Britain, have been shorn of some part of their live forces, and have had to draw on their capital for over four years. Whole tracts of countries, not a few among the richest in the world, Belgium, Northern France, Poland, Galicia, Rumania, Serbia, have been laid waste. It was, therefore, a delusion to fancy that the enormous needs arising out of the destructiveness of war were going, on the morrow of peace, to stir up a revival of activity all round and to call forth an intensive movement of international exchange. While creating such needs, war destructions had, at the same time, done away with the means to satisfy them. A ruined land is a closed market. In the very ratio to the mass of wealth that had disappeared, exchanges of commodities were bound to become restricted. The deepestlying cause of the present crisis is that the world nowadays possesses a productive equipment that vastly exceeds its reduced capacity of consumption. So lean has grown the body 
that its armor hangs loose and weighs too heavily on it.

\section{War Alone Responsible}

For this trouble, war, war alone is responsible. Whence does it come, then, will you say, that this trouble has grown worse in certain countries since the peace? Whence is it that Austria, Hungary, Poland, for instance, in 1922 are worse off than in 1919, some of them indeed in the depths of misery?

First, it is because such a violent disturbance as the recent European upheaval cannot everywhere subside at the same rate, under the magical spell of the treaties. The mere signing of them has not always proved sufficient; could not possibly always have proved sufficient to bring back actual peace. Even after they had been signed, war went on with its destructive work in several parts of Europe. Such has been the case with Poland, which found itself compelled to settle by the law of arms the fate of its eastern frontier. Such has been the case with Hungary, where revolution and civil war have carried on for months the mischief of foreign war. Such has been the case with Rumania, Jugo-Slavia, Czecho-Slovakia, which have had to keep their armies mobilized, with the Russian and the Hungarian revolutions at their doors.

People forget, moreover, that peace only made manifest the long-protracted demoralizing process of the war. Under the influence of the war, the peoples had become used to living from hand to mouth, to spending money without any foresight. The true notion of the value of things had been wiped off in most minds. As long as war was going on, however, every nerve of discipline and work had to be kept strained. The moment peace came, they suddenly became unstrung. By a natural reaction there grew up a general spirit of laziness, along with a taste for extravagant, improvident, often useless expenditure. The Western nations, as a rule, got over it pretty quickly. In Eastern Europe, there has been a more lasting demoralization. It is a fact that too many Eastern nations, while exerting themselves less, have gone on since the peace incurring an expenditure out of proportion to their resources, mortgaging the future in order to meet present requirements.

Thus, both from the material and from the moral point of view, whole districts in Europe have remained, since the peace, the victims of war; and it is this long-drawn aftermath of the world catastrophe which has piled up more ruins on the top of those that had been heaped up by the catastrophe itself.

We must, therefore, be careful not to lay to the account of peace the harm wrought by the war-a war which in too many places has too long gone on under the deceitful pretence of peace.

When people write that reparations, such as have been provided for in the Versailles Treaty, are the root of the present woes of Europe, they are laboring under a singular optical delusion. They assume, at bottom, without saying it in so many words, that the Treaty has raised the problem of reparations. For our part, we think the raising of this problem is rather due to the laying waste of the wealthiest provinces of France and of a small stretch of Belgium by the armies at the front. The Peace Treaty has done nothing but decide that those destructions were to be made good, not by those who had suffered them, that is to say the French and the Belgians, but by those who had carried them out, that is to say the Germans. It has barely declared that those were to be made poorer who were chiefly 
responsible for the impoverishment of all. For this impoverishment it is not a bit more responsible than is an expert for the amount of the damage he assesses, or a judge for the crime he punishes.

Under such reservations (and most necessary they are), it could not very well be contended, however, that treaties which have upset the whole political map of Europe have been without any influence on the course of European economic life, and have not contributed their share to the present disorder. It was bound to be so.

\section{Principles of Versailles Treaty Not EсоNomic}

The guiding principles of the Versailles Treaty and of its fellows were not economic principles. They could not be; nor are they to be blamed for it. It is not desirable that the material needs of men should ever hold sovereign sway over the destiny of nations. It is quite legitimate that the authors of the peace should have considered, above all, moral and political factors, and that they should have aimed, before anything else, at restoring the rights of peoples and the peace of Europe. That is not to say, indeed, that economic requirements have been left altogether out of reckoning by them: the Dantzig and the Saar arrangements are sufficient evidence to the contrary. Yet it cannot well be denied that they held this class of considerations to be secondary. While remapping central Europe, they have unquestionably disturbed its economic balance. If there has been such a thing as "Economic Consequences of the Peace," they are to be looked for in this direction; the more so as such consequences are possibly not beyond remedy, and the remedy might be suggested by carefully going into them.
As a matter of fact, when statesmen, economists, manufacturers and business men think of the economic reconstruction of Europe, the natural process is for them to look backward, mentally to visualize the main currents of trade that used to run across it before the war, to measure the strength of those currents and finally to cast about for some means to restore them in their former intensity.

\section{Havoc Wrought by Shifted Boundaries}

History no doubt never repeats itself. It is a wise thing, all the same, not to turn our backs deliberately upon the past. The economic reconstruction of Europe will, in the last resort, mean the setting up of a fabric, made out of both new materials and of a number of old materials, where producers and business men will feel sufficiently at home. We shall therefore be attempting no vain task, if we inquire in what way the shifting of the frontiers has modified the economic structure of Europe, and what distempers have followed upon this trafficdisturbing surgical operation.

In Germany.-Germany has had large pieces cut off: her Polish provinces in the east, her French provinces in the west. Indisputably, the life of the German economic organism was closely bound to that of the whole world. Owing to her productive power and to the vigor of her commercial expansion, her activity was spreading beyond the boundaries of the Hohenzollerns' Empire and even of Middle Europe. Yet it was in her own territory, such as defined by her political frontiers, that Germany used to find the essential elements of her prosperity. Those elements were twofold. Not only had the toil of her nationals known how to set to work upon her abundant natural resources; it had also 
succeeded in setting up between the different provinces a close coöperation, in knitting the various parts of the Empire together into one single whole. Had the line of the new frontiers done nothing but make Germany smaller, diminishing the total amount of her wealth, the resulting economic disturbance would have been comparatively trifling. But it has done more: it has, in a certain number of cases, destroyed the connection of the parts, dammed up well-established channels, broken the equilibrium of the whole. Of what precisely has this work of dissociation consisted?

The German exponents of the idea of "economic autarchy," who were dreaming, before the war, of making the Reich self-contained, its supplies depending in no way on the rest of the world, were only translating into the language of theory one of the fundamental characters of the structure of their country, namely, the spontaneous division of labor between the rural east and the industrial center and west of Germany. As far as mere outward signs go, the Oder might seem to divide the Empire into two entirely distinct economic worlds: on the left hand, the land of the big towns, the freehold of the industrial magnates; on the right, the Prussia of agrarian Junkers, the low-lying plain entirely devoted to the cultivation of the ground. But, dissimilar as they were, and by reason of their very dissimilarity, each lived for the other and with the help of the other. Eastern and western Prussia, Pomerania, Posnania were the great granary of Berlin, of Saxony, even of Westphalia. Western industry, for many years, had become the only raison d'être of the agricultural wealth of the east. Not only did the millions of workmen congregated around its factories provide a never saturated market, but from there did the huge landed estates of the east draw their machines, their potash, their chemical manures; Prussian agriculture had become intensified, industrialized under the same impulse and after the same model. Both had thriven alongside each other, under the influence of a common stimulus. By breaking up the agricultural land of the east, by dividing it between the new Germany and the new-born Poland, the Versailles Treaty has destroyed this solidarity.

Though dealing with less extensive interests, the way in which the Treaty has sundered, in the west, the Lorraine and Saar metallurgical group from the Ruhr basin, has none the less smashed another vital piece of the German economic organization. As everybody knows, Germany, by the Frankfurt Treaty, had secured for herself in 1871 the possession of the iron-ore deposits which were then considered the richest and the only ones that could be used. Ever since that time, it had been a deliberate policy to work this metallurgical wealth in close conjunction with the coal wealth of the Ruhr. With but few exceptions, the steelworks erected on the Lorraine iron ore had been started by Westphalian manufacturers in order to supplement their Westphalian plant. With an output of pig iron, half-finished products and rolled material, they were mostly engaged in supplying the engineering and finishing works of the Ruhr. The Ruhr was their market. On the other hand, the Lorraine and Saar iron and steel industry could not have worked without the coking coal and the coke of Westphalia. Thus had an intimate connection, both industrial, commercial and financial, been developed between the two districts by the nature of things and the will of men. The handing back of Lorraine to France, 
the setting up of the Saar territory have dislocated this system.

At the same time, the loss of the Alsace desposits was upsetting the conditions of another German industry, and a most important one: the potash industry. A few years before the war, the discovery of those deposits had come as a threat to the monopoly hitherto held over the world market by the Thuringian operators. The danger had been averted through the organizing of an official compulsory trust. The share to be produced by Alsace had been strictly rationed, in compliance with the interests of the Thuringian center. The Kalisyndicate, where the industry of central Germany held a controlling vote, had taken in hand the whole policy, regulating production, allotting the amount of sales, fixing prices. At present Thuringia alone remains under its control. The Alsatian field, having become French, has recovered its autonomy. Competition has taken the place of coöperation. French potash and German potash are at war on the world market. When losing its hegemony, the German potash industry has most certainly lost one of the essential conditions of its prosperity.

Those are the chief pieces of the German economic machinery which the Versailles Treaty has twisted and put out of gear. They were too important for the effect of their disadjustment not to be felt as well outside the new frontiers of the Reich. In spite of all the precautions taken by the Peace Treaty, German bad will has been able, for instance, seriously to hinder the coke supply of the Lorraine iron and steel industry. Again, even though it has been possible for the Alsace potash field, through the freedom that has been restored to it, to work on a more extensive scale, Ger- man competition has been so keen as to make its situation pretty awkward at times.

In Austria-Hungary.-Even more than the dismembering of Germany, the destruction of Austria-Hungary was bound to disturb the general economy of Europe.

A paradox of political architecture, the Dual Monarchy was all the same a homogeneous well-devised economic fabric. Its political function in the Europe of old essentially was, through wonders of internal diplomacy, to keep in comparative peace and in an everthreatened state of equilibrium a chaos of rival inter-locking nationalities. Such a miracle, one is entitled to assume, it would not have performed so long, were it not that it met an economic requirement. Contrasting with its political complexity, the simplicity of its economic build strikes one at first sight. Two groups of territories, an industrial one in the west, an agricultural one in the east, supplemented each other within its boundaries. Most of the industries in Bohemia, Moravia, Austria and Styria found both their natural outlets and their supplies of raw materials in Hungary, Galicia, Bosnia and Herzegovina; conversely, the industrial centers of the west were the chief markets of Hungarian corps, Galician oil and Galician pigs, Carpathian and Transylvanian timber. Inside each group, again, the different provinces had become united by close ties. The Czech textile industry, for instance, used to work up the raw material supplied by Vienna, which in its turn sold the manufactured article; from Hungary, Galicia would buy the wheat and flour she lacked. A continual process of mutual exchanges, made easy by the fact that there were no customs barriers, made a living unit out of this conglomerate of rival, ill-assorted nationalities. 
Their unity found its expression in the preponderance of Vienna, not unchallenged indeed as a political capital, unchallangeable as an economic capital. A town of two million inhabitants, a big railway junction, a stage in the Danube navigation, Vienna was one of the chief European markets, a distributing center admirably located on the fringe of the Balkan world. Its radius of action stretched as far as Salonika and Constanza. Its old banking experience made it the financial regulator of the whole economic movement in SouthEastern Europe. The break-up of the Dual Monarchy and the multiplication of state boundaries henceforth prevent it from doing the duty for which its long specialization had perfectly fitted it. From a center of life, it has thus been turned into a breeding-place of economic disease.

The peace has done nothing but seal the destruction of the AustroHungarian State, which had become a political impossibility. It would have done wisely, no doubt, not to sunder ruthlessly the economic connections that had grown out of this long existence. The solidarity of a system several centuries old cannot be dissolved without every one of the members thus separated experiencing serious disturbances. Every one of them, at this time, suffers from this brutal parting, and the whole of Europe unquestionably suffers along with them. In order to reconstruct, it will be necessary again to make into one economic body what has been dismembered politically.

In Poland.-It is a re-jointing of this kind which the makers of the Peace Treaty seem to have achieved on the borders of the Eastern world. By resuscitating the Polish State, one would say at first sight that they have called to life a perfectly sound eco- nomic organism. The union of what used to be Russian Poland, an industrial tract to which has been added the larger part of Upper Silesia, with agricultural Posnania and Prussia and with Galicia which produces raw materials, makes up a unit which, one would think, contained within itself every possible element of equilibrium.

But let us look back and ascertain what sort of life was that of the various parts of present-day Poland when they were separate.

One fact strikes us at once, pregnant with ominous potentialities: the three essential components which at present make up the economic framework of the new state were, from the point of view of economics, with political and customs barriers between them, as strange to each other as any neighbors can well be. Each was deliberately turning its back on the others.

The industry of Congress Poland, its main source of wealth, chiefly depended on the Russian market. From 1910 to 1912, the total exports of Congress Poland have been estimated at 1,800 million gold francs a year; of those polish exports, 90 per cent, that is to say, 1,600 million francs, went to Russia, 1,400 million of which consisted of manufactured articles. About the same time, the annual value of industrial production in Congress Poland was stated to be 2,800 million francs. Thus Russia alone took in more than one-half of the Polish industrial output.

It was Germany, on the other hand, as already pointed out, which consumed the major part of the agricultural production of Greater Poland, i.e., Prussian Poland. Railway consignments have made it possible to calculate roughly the volume of business Posnanian agriculture used to carry on with the remainder of Germany. It is considerable. About 1907, in Pos- 
nania, the excess of the sales over the purchases of cereals and milling products amounted to $4,820,000$ quintals. In 1900, the city of Berlin alone bought 100,000 head of cattle and 747,000 swine of the Posnanian breeders; Silesia, 42,000 cattle and 132,000 swine; Saxony (kingdom and province), 17,000 cattle and 127,000 swine. Posnania exclusively worked for the German market, borrowing one single item from Russian Poland, to wit: agricultural labor.

As regards trade relations between Russian Poland and Austrian Galicia, they were practically non-existent. In 1911, Galician sales in Russian Poland amounted to 65 million francs only, purchases to 64 million. The whole stream of Galician commercial activity was flowing towards the other Austrian provinces, Hungary and Germany. From Hungary alone, Galicia, whose agricultural production did not cover her own needs, had to get 2,500,000 quintals of flour; the 250 to 300 million francs' worth of cloth she imported came from Bohemia, Austria and Germany; to Germany and Austria, the hundreds of thousands of workmen went to work whom she exported every year in order to make good the deficit of her trade balance.

Present-day Poland, therefore, is nothing but a juxtaposition of groups, ethically connected indeed, but which have been kept apart so long that they have become accustomed to live along divergent lines. Economically, she is a potentiality, not an actuality. In order to go on living in a normal way, it would have been necessary for each of the component parts to remain in close touch with its former associates. As ill-luck would have it, on the contrary, Poland around her cradle has found nothing but inimical feelings. Is it to be wondered at, that, under such circumstances, her rehabilitation, rather say her organization, should have proved so difficult a task?

The problems that are raised by the existence of rejuvenated Poland loom in a particularly anxious light when you ponder on the future that may be in store for Polish industry, the economic backbone of the new state. That industry used to thrive on her union with Russia, where one half of her production, as we have seen, found its outlet. Western Europe was completely closed to it. Before the war, Germany bought of Russian Poland a mere 100 million francs' worth of commodities a year, mostly agricultural produce, selling her in return over 7.00 million worth: some raw materials and a large quantity of manufactured articles.

Thus the office of Poland in the European economic system was a clearly-defined one: a market for German industry, she in her turn poured her own products into the empire of the Tsars. What profits she made in the Russian market, she spent buying in Germany. She was the main stage in the great commercial way leading from Western centers of production to Russian centers of consumption. That was her essential function. That is the function she is no longer able to fulfil at the present day. Revolution and anarchy have shut off the market on which she used to depend; they have dried up her chief source of income. The same blow has stopped the big commercial current that used to flow from Germany toward Kien and Moscow, no doubt for many years to come. Not a few European conferences will meet, in all likelihood, before it is reestablished. The collapse of Russia has for many a long day done away with one of the essential elements of Polish life and of Central European prosperity. 


\section{Conclusion}

Such are the obstacles which the changes in political geography have thrown across the normal trade currents with which the organization of pre-war Europe had made business men familiar.

Were it not altogether useless to ply the authors of the Peace Treaty with retrospective criticism, one might say theirs has been a sin of omission rather than of commission. They have been anxious to set the people free and to found peace on right; the conscience of mankind would not have allowed them to do otherwise; there are times when it is proper to philosophize before living. Yet at the same time they have now and then omitted closing and dressing the wounds they had inflicted while carving into the European body. They might have kept some of the arteries where life-blood was circulating more widely opened. They have done it in certain cases. Perhaps it would have been necessary to supplement the Treaties where the political status of the new Europe was being laid down with a complete set of economic agreements.

This duty, which has been almost entirely left over by them to their successors, the great Genoa Conference could have shouldered, and perhaps could have made a success of it. It could, by international arrangements with regard either to customs or traffic, have attempted to lower the gates that interfere with inter-European trade. Treaties of commerce, credit, labor, calculated to restore the equilibrium that has been destroyed, ought to have been prepared or even worked out within its precincts between the younger states and the older ones as well. Private international agreements could have been adumbrated there, in a friendly atmosphere, between producers of all sorts, so as to draw together again the bonds that have been snapped by the war or by the treaties.

We have good reason to think that such was indeed the reconstruction program of France, a modest one perhaps, but on positive lines. The Conference has chosen, instead, to strike a different path and stumble there. 